\title{
ANNUAL REPORT OF THE ESTONIAN NATURALISTS' SOCIETY (2010)
}

\author{
Silja Kana, Tõnu Viik \\ Estonian Naturalists' Society, Tartu, Estonia
}

Hereby we give the short version of the annual report of the Estonian Naturalists' Society for the year 2010.

Our Society was founded in 1853 and it was associated with the Estonian Academy of Sciences on 23 January 1998.

The Society lists 749 active members, 14 honorary members and 635 trustees, thus being one of the biggest societies in Estonia.

The Society consists of the following subunits:

1. Assembly of Ecology

2. Estonian Teriological Society

3. Estonian Malacological Society

4. Jakob von Uexküll Centre.

5. Section of Botany

6. Section of Entomology

7. Section of Forestry

8. Section of Geology

9. Section of Anthropology

10. Estonian Mycological Society

11. Section of Theoretical Biology

12. Lake Commission

13. Section of Amateur Meteorologists

14. Commission of Natural Education

15. Commission of Terms in Ecology

16. Round Table of Nature Conservation

17. Commission of Botanical Rarities

18. Library Commission 
19. Commission of Plant Names

20. Assembly of Honorary Members

21. Commission of the Observational Networks

22. Commission of the History of Natural Sciences

\section{GENERAL ASSEMBLIES}

In 2010 nine General Assemblies with scientific presentations and one special meeting were held:

- January 28 - Helle Mäemets: "About estimating the quality of lakes".

- February 25 - "The Baer day".

\section{Presentations}

1) Erkki Tammiksaar: "K.E. V Baer and Russian espionage - myth and reality".

2) Maarja Öpik: "The diversity of fungi forming arbuscular mycorrhiza".

- March 25 - Riinu Rannap: "Threatened amphibians in Estonia and their protection management", the review meeting of 2009.

- April 15 - a special meeting, the Board of ENS answers the members' questions.

- April 29 - Silver Rattasepp: “About culture using evolutionary terms".

- May 27 - Ivo Leito: "About acids and bases: from different viewpoints".

Kai Reemann: "About the library and the electronic database of the library ENS".

- September 30 - Peeter Olesk: "Strategy of writing textbooks and professor Julius Tehver".

- October 28 - Ain-Elmar Kaasik: "Multidimensional medicine".

- November 25 - 100 anniversary of Neeme Mikelsaar in the Centre of Limnology.

\section{Presentations}

1) Tarmo Timm: "Life with Neeme Mikelsaar".

2) Ain Järvalt, Ervin Pihu, Teet Krause: "The surveys of fishery of inland waters yesterday and today". 
3) Ain Järvalt: "The overview of the activities of the Centre of Limnology".

- December 16 - Olav Renno: "Revival of the nature conservation in Estonia after the World War 2 (1944-1966)".

\section{SECTIONS' MEETINGS}

\section{Section of Botany}

February 3 - Inga Hiiesalu: "The hidden world of plants - belowground diversity".

December 8 - Malle Leht: "About XXIII Conference-Expedition of the Baltic botanists in Haapsalu".

\section{Estonian Teriological Society}

May 21 - Lauri Klein: "Roads and crossing points for the animals".

\section{Section of Forestry}

February 25 - Tiit Maaten: "Review of plantations of experiments created by the instructions of professor E. Pihelgas".

April 22 - Marek Metslaid and Kajar Köster: "Studies about storm damages and forest fires".

June 15 - Heino Kasesalu: "Review of Valdek Ritslaid's life and activities".

November 3 - Meelis Seedre: "Dynamics of carbon in boreal mixed forest".

December 15 - Mats Varik: "About the growth dynamics in Alnus and Betula stands".

\section{Section of Geology}

January 21 - Vincent Perrier: "Geology of France".

March 4 - Igor Tuuling: "On the hiking trails of Patagonia".

April 20 - Randal Keynes: "Recollections on Charles Darwin's inquisitive mind".

April 22 - Ann Kraut: "The presentation with photos of some stones: how I visited Tenerife and what I saw".

May 20 - Martin Liira: “А бы что, геологи? - possibilities of ski hiking in Russia". 
November 18 - Oive Tinn, Leho Ainsaar and Vincent Perrier: "Geological expedition to Canada, the island of Anticosti".

December 9 - Vincent Perrier: "Dinosaurs and other vertebrate bearing deposits from France".

\section{IMPORTANT EVENTS AND CONFERENCES}

1. The $11^{\text {th }}$ Estonian conference on ecology "Diversity and ecosystems", Tartu, 8-9 April. (In the framework of the UN International year of biodiversity).

http://www.lote.ut.ee/geo/okoloogiakonverents. (together with the University of Tartu Centre of Excellence FIBIR, Institute of Ecology and Geosciences, Natural History Museum and the Estonian University of Life Sciences)

2. Science day dedicated to Karin Mark "Gender and gender roles". April 9, Tallinn (together with the Tallinn University Institute of History and the NGO Centre of Archeology).

3. Mushroom practice, the island of Vormsi, May 13-16.

4. The Spring School of Theoretical Biology "Theory of movement". May 21-23, on the Kopra farm, Viljandi County (together with the University of Tartu Institute of Ecology and Geosciences, and the Natural History Museum).

5. Gathering of the friends of mosses, May 22-23, on Kesselaid.

6. Tha Naturalist's Day XXXIII, June 19, in Tartus and in landscape reserve of Vapramäe-Vellavere-Vitipalu.

7. The Summer School of Ecosemiotics with the Institute of Philosophy and Semiotics of the University of Tartu. July 10-11, Nüpli.

8. The $23^{\text {rd }}$ Conference-Expedition of the Baltic Botanists "Seminatural habitats". July19-22, in Haapsalu.

9. Gathering of amateur meteorologists and thunder observers. July 24, in Tartu.

10. Mushroom practice, on Vormsi, September 16-22.

11. The Autumn School of Teriology, in Ähijärve, September 17-19.

12. The Autumn School of Geology VI "Global changes". October 410, in Roosta, Läänemaa.

13. The Conference commemorating Juhan Aul (1897-1994). October 14. 
14. The Conference commemorating Neeme-Õnneleid Mikelsaar (1910-1980, November 25, the Centre of Limnology.

15. The Meeting of Mycological Society "Actiones". December 11, Tallinn, the Estonian Museum of Natural History.

\section{PROJECTS}

The Society participated in fulfilling the projects funded by the Environmental Investment Centre, Tallinn Botanic Garden and the Ministry of Environment.

\section{LIBRARY AND PUBLICATIONS}

In December 2010 there were 161,891 printed items in ENS library. Within a year the library reviewed 154 new books and items of 187 periodicals. The publications were exchanged in the reporting year with 54 institutions and organisations from 18 countries.

\section{Publications}

1. Öpik, M. and Puura, I. (eds.) 2010. Scola Biotheoretica 35 "Theory of Origin". $128 \mathrm{pp}$. (together with University of Tartu Institute of Ecology and Geosciences and the Natural History Museum).

2. Preeden, U. and Laumets, L. (eds.) 2010. Schola Geologica 6 "Global changes" 152 pp. (together with University of Tartu Institute of Ecology and Geosciences, Tallinn Technical University Institute of Geology and the Department of Mining).

3. Folia Cryptogamica Estonica 47. 107 pp. (with the University of Tartu)

4. The $23^{\text {rd }}$ Conference-Expedition of the Baltic Botanists. Abstracts and Excursion Guides. Haapsalu, Estonia, July 19-22, 2010. 92 pp. Tartu Ülikool, Eesti LUS, EMÜ, PKÜ, EL

\section{Internet journal}

Ingerpuu, N., Vellak, K. (eds.) 2010. Friend of mosses 13. 24 pp. (http://www.botany.ut.ee/bruoloogia/Samblasober13.pdf) 


\section{OTHER ACTIVITIES}

- ENS and The Estonian Environment Information Centre are developing the Nature Observation Database. The overview of 2010: $\mathrm{http}: / /$ eelis.ic.envir.ee/lva/LVA.aspx?type=Artikkel\&content $=60783$ 6056

- The commission of plant names continued to complement the database of plant names. During 2010 altogether 226 records were entered.

- ENS with the Estonian Fund for Nature and Estonian Green Movement made an accusation against Finnish governmental institutions in the case of the Nord Stream pipeline.

- Seven seminars from the series "From natural scientists to teachers of natural sciences" were held. 